\title{
Investigation of The Genotoxicity of Ponceau $4 R$ in Drosophila Melanogaster Using the Smart Test and Effects of Some Plants Extracts Against the DNA Damage
}

\author{
Aylin YILMAZ ÇETINKKAYA ${ }^{1 *}$ Selçuk YURTSEVER ${ }^{2}$ \\ 1. Keşan Hakkı Yörük School of Health, Turkey Trakya University, 22800 Keşan, Turkey \\ 2. Biology Department, Science Faculty, Turkey Trakya University, 22030 Edirne. Turkey \\ * E-mail of the corresponding author: aylincetinkaya@trakya.edu.tr
}

\begin{abstract}
In this study, genotoxic effects of Ponceau 4R (E 124) was investigated in vivo using Drosophila melanogaster Meigen in the laboratory experiments. The food coloring in $25 \%, 50 \%$ and $75 \%$ concentrations were added to food medium of Drosophila during the larval stage and the mutant wing spot numbers were evaluated using the wing spot test, namely SMART (somatic mutation and recombination test). The food colourings are the food additives which are used for increasing the appearance of food and beverages.

In SMART, mwh (multiple wing hair), flr3 (flare) and BdS (beader serrate) marker genes on the third largest chromosome of Drosophila are used. Genotoxic effects of the Ponceau 4R in the imaginal disc cells that will develop into the wing spot cells during the embryonic development of Drosophila heterozygous larvae and the genotypic changes caused by mutation or recombination in somatic cells also play a role in the formation of mutant spots in the wings (GRAF et al., 1984).

The food coloring which is daily used in our many types of food induced mutant wing spots depend on the concentration in trans-heterozygous flies $(\mathrm{mwh} / \mathrm{flr} 3)$ and in balancer-heterozygous flies (mwh/TM3) in the medium (Chi-Square test; $\mathrm{df}=3, \mathrm{P}<0.001$ ) and the spots were significantly higher than the flies were fed in the medium prepared with distilled water used as negative control showing that the Ponceau $4 \mathrm{R}$ has mutagenic effect. However, the mutant spots were less than the flies were fed in the medium prepared with 1 mM EMS (ethyl methane sulfonate) used as positive control showing that mutagenic effect of the colouring was not as much as the EMS.

On the other hand, the concentrations of the colouring were used in the mediums together the different plant extracts to determinate whether they have antigenotoxic effects against the colouring. The following plant extracts were added to mediums in $10 \%$ concentration with the colouring were: Hypericum perforatum L., (St John's wort), Silybum marianum (L.) Gaertn. (milk thistle), and Lavandula stoechas L. (topped lavender). The mutant wing spots were compared to control groups showed that the three plant extracts have no effect to reduce the mutant spots in trans-heterozygous flies $(\mathrm{mwh} / \mathrm{flr} 3)$ and in balancer-heterozygous flies and thus have no antigenotoxic effect against the food colouring used experimental treatments (Kruskal-Wallis test; $\mathrm{df}=2, \mathrm{P}>0.05$ )
\end{abstract}

Keywords: Challenge Genotoxicity, antigenotoxicity, Ponceau 4R, Hypericum perforatum L., Silybum marianum (L.) Gaertn., Lavandula stoechas L., Drosophila melanogaster Meigen, SMART.

DOI: $10.7176 /$ JHMN/87-07

Publication date:March $31^{\text {st }} 2021$

\section{Introduction}

Nutrition is one of the most important factors for the continuity of life. Today, it is seen that people's eating habits differ greatly as a result of changes in lifestyle and economic development. Although the use of food additives has a large place in the food industry, its effects on human health are also a current issue under discussion. As a result of the increase in ready-made food consumption with urbanization, potential health risks occur with the exposure of the body to more additives (AKBULUT, 2011).

Synthetic food colourings, which are a commonly used class in food additives, can cause genotoxic effects as well as health problems such as allergic reactions, skin rashes, asthma, hyperactivity and concentration disorder when not used within legal restrictions (YENTUR et al., 1996). It is also stated that the food colouring agents cause hypersensitivity, migraine, preterm delivery, salicylate sensitivity and cancer (MAIER et al., 2010). With 
genotoxicity tests and epidemiological studies on Drosophila, mouse, rat and bacteria, synthetic the food colourings have been reported to be carcinogenic in uses that do not comply with the regulation to demonstrate high quality (YENTUR et al., 1996; SARIKAYA et al., 2010). It has been determined that the level of the food colourings used in studies related to the subject in our country is well above the statute limits and may have harmful effects in terms of public health (YENTUR et al., 1996; TOPSOY, 1990; YAMAN, 1996).

Many studies of human disease have shown that Drosophila melanogaster Meigen, down-organized eukaryotic organism can be used instead of mammals. Because, the biological properties of the imaginal disc cells in Drosophila larvae undergo proliferation and differentiation to form body parts in the adult stage are similar to many cancer-sensitive mammalian cells, and more than $60 \%$ of genes identified in human genetic diseases are common with the genes in Drosophila genome. Drosophila, is frequently included as a model organism in SMART test. This test is suitable for detecting mutagenic and recombinogenic activities are as a result of genotoxic and antigenotoxic effects in somatic cells induced by chemicals. When SMART compare with the other tests, it is quite fast, precise and economical (BERNARDS \& HARIHARAN, 2001). Also, this in vivo test method in Drosophila, may be associated with in vivo genotoxicity tests in mammals (GRAF et al., 1984; GRAF \& WURGLER, 1996). Mutations induced by chemicals in somatic cells of Drosophila larvae are transferred to daughter cells with the several cell divisions in wing SMART. Genotypic changes caused by mutation or recombination in somatic cells appear as mutant spots in the wings (GRAF et al., 1984; TRIPATHY et al., 1989).

Ponceau $4 \mathrm{R}$ was preferred to use in the study because there are very few scientific publications similar to the subject of the research in the literature. To be expressed in more detail; There was no study about Ponceau 4R in Drosophila using SMART. There are a limited numbers of studies on Drosophila about the genotoxicity of the food colouring. In addition, there is no study in the literature about the plant extracts selected for use in the study, which are widely used among the public and thought to eliminate mutagenic effects, are evaluated by SMART in Drosophila. While there are limited numbers of studies on the antigenotoxicity of Hypericum perforatum L. in Drosophila, there is no study about Silybum marianum (L.) Gaertn. and Lavandula stoechas L.

The research has been conducted to determine whether Ponceau $4 \mathrm{R}$ in $25 \mathrm{mg} / \mathrm{ml}, 50 \mathrm{mg} / \mathrm{ml}, 75 \mathrm{mg} / \mathrm{ml}$ concentrations will have a detrimental effect on D. melanogaster Meigen's mwh (multiple wing hair-multiple wing hair) and flr3 (flare-irregular wing hair) lines and Hypericum perforatum L., Silybum marianum (L.) Gaertn. and Lavandula stoechas L. in $100 \mathrm{mg} / \mathrm{ml}$ concentration which are stated to have anticarcinogenic effects in many sources, will be successful in reducing the genotoxic effect of the colouring or not using wing SMART.

\section{Materials and methods}

\subsection{Culture of Drosophila Lines}

D. melanogaster Meigen lines used in the study were obtained from Trakya University and Akdeniz University, Science Faculty, Biology Department. Drosophila flies were cultured in an incubator where optimum living conditions $\left(25 \pm 1{ }^{\circ} \mathrm{C}\right.$ and $40-60 \%$ relative humidity) were provided and adjusted to 12 hour light and 12 hour dark time period.

\subsection{Creation of Experimental Groups}

In determination the mutagenic and/or recombinogenic effects of Ponceau 4R (E 124) and antigenotoxic effects of the plant extracts against the colouring in D. melanogaster Meigen lines SMART developed by (GRAF et al., 1984) was used.

\subsection{Genetic Structure of Drosophila Mutant Strains}

In Drosophila wing SMART, the mwh, flr3 and BdS (beader-serrate) marker genes on the third largest chromosome of Drosophila are used. In Drosophila wing SMART, flr3/TM3, BdS virgin females and mwh/mwh males are used for normal metabolic activity cross (LINDSLEY \& GRELL 1968; LINDSLEY \& ZIMM 1992; GARCIA-BELLIDO \& DAPENA 1974).

Experiments of the application groups consisting of experimental, treatment and control groups in the study were conducted simultaneously. Distilled water was used in the negative control group and EMS (KASIMOĞLU \& UYSAL 2016) is stated in the literature that it has a mutagenic effect, was used in $1 \mathrm{mM}$ concentration in the positive control group. The food coloring and the plant extracts used in the application groups were dissolved in distilled water. Ponceau 4R in 25\%o, 50\%o and 75\%o concentrations in the experimental group and Hypericum 
perforatum L., Silybum marianum (L.) Gaertn. and Lavandula stoechas L. in $10 \%$ concentration with the concentrations of the coloring were used for Drosophila larvae at $72 \pm 4$ hours.

D. melanogaster Meigen lines were fed with a standard Drosophila medium when kept in stock and in a cross bottle to perform fertilization and embryogenesis to obtain heterozygous larvae. Drosophila instant medium was used for Drosophila larvae at $72 \pm 4$ hours in the experimental, treatment and control groups. Drosophila instant medium and the food coloring and the plant extracts used in the study were purchased commercially. Drosophila instant medium was obtained from Carolina Biological Supply Company. Ponceau 4R was from Roha JJT Group Company. Hypericum perforatum L. (St. John's wort) and Silybum marianum (L.) Gaertn. (milk thistle) were from Solgar and Lavandula stoechas L. (topped lavender) was from Herbal Pharm and EMS was obtained from Sigma Aldrich GmbH.

\subsection{Applications of Experimental Groups}

Larvae in groups of 100 were left into falcon tubes where $1.5 \mathrm{~g}$ of Drosophila instant medium wetted with $5 \mathrm{ml}$ of solutions containing in 25\%o, 50\% and 75\% concentrations of Ponceau $4 \mathrm{R}$ and/or the plant extracts in $10 \%$ concentration. While the wing edges of the adult flies developed from trans-heterozygous larvae (mwh/flr3) in each concentration of application groups have normal structure, the wing edges of the balancer-heterozygous flies (mwh/TM3) are in the form of serrate. In evaluation, 40 wings were used for each concentration in all application groups. Slides of normal and serrate wings were examined using a light microscope under $40 \times 10$ magnification to detect the presence of mutant clones (KAYA, 2000). Classification of types were according to mutant clones: Small single spots containing of 1-2 mwh, large single spots containing $\geq 3$ mwh or $\geq 4$ flr 3 and twin spots containing adjacent mwh and flr3 cells (GRAF et al., 1984).

\subsection{Wing spot test (SMART)}

The SMART assay principle is based on loss of heterozygosity in recessive marker genes; mwh and flr3on the third largest chromosome lead formation of imaginal disc cells in Drosophila heterozygous larvae into mutant wing spots cell by mutation or recombination (GRAF et al., 1984).

\subsection{Statistical Analysis}

Minitab package program was used in the statistical evaluation of the study results. In the analysis of the study data, it was investigated whether the total numbers of mutant spots in the wings of the flies in the positive and negative control groups was statistically different with the Chi-Square test $(\mathrm{df}=1)$. Chi-Square test $(\mathrm{df}=3)$ was used in the analyzes where the total numbers of mutant spots in the wings of the flies in experimental and treatment groups were compared separately with those of the flies in the positive and negative control groups. The total numbers of mutant spots in the wings of the flies in experimental and treatment groups were compared with each other and whether there was a statistical difference was determined by the Chi-Square test $(\mathrm{df}=2)$.

Possible differences between the average of the total numbers of wing mutant spots of flies grown in experimental and treatment groups were compared with Non-Parametric Kruskal-Wallis test ( $\mathrm{df}=2$ ).

The average of the total numbers of mutant spots in the normal and serrate wings of the flies in all experimental groups were compared with the Mann-Whitney U test.

In all evaluation, the total numbers of wing mutant spots obtained from the study and presented as Fr (Frequency) values and the differences below $\mathrm{P}<0.05$ were considered to be statistically significant. 


\section{Results and discussion}

Table 1. Mutant clones in mwh/flr3 wings obtained from experimental group, treatment group, positive and negative control groups

\begin{tabular}{|c|c|c|c|c|c|c|c|c|c|c|c|c|}
\hline $\begin{array}{l}\text { Application } \\
\text { groups/ } \\
\text { Concentration }(\mathrm{mg} / \mathrm{ml})\end{array}$ & $\begin{array}{l}\text { Number } \\
\text { of wings }\end{array}$ & $\begin{array}{l}\text { Small } \\
\text { spots } \\
(1-2 \text { c }\end{array}$ & & $\begin{array}{l}\text { Large } \\
\text { spots } \\
(>2 \text { cel }\end{array}$ & & Twin & pots & $\begin{array}{l}\text { Total } 1 \\
\text { spots }\end{array}$ & & & To & al spots ${ }^{\mathrm{X} 2}$ \\
\hline & & No & $\mathrm{Fr}$ & No & $\mathrm{Fr}$ & No & $\mathrm{Fr}$ & No & $\mathrm{Fr}$ & No & $\mathrm{Fr}$ & \\
\hline Distilled water & 40 & 3 & $(0.08)$ & 5 & $(0.13)$ & 4 & $(0.13)$ & 3 & $(0.08)$ & 12 & $(0.30)$ & \\
\hline $1 \mathrm{mM}$ EMS & 40 & 49 & $(1.23)$ & 130 & $(3.25)$ & 68 & $(1.70)$ & 99 & $(2.48)$ & 247 & $(6.18)$ & $a^{* * *}$ \\
\hline 25 Ponceau 4R & 40 & 1 & $(0.03)$ & 37 & $(0.93)$ & 0 & $(0.00)$ & 1 & $(0.03)$ & 38 & $(0.95)$ & $\mathrm{a} * * * \quad \mathrm{~b} * * *$ \\
\hline 50 Ponceau 4R & 40 & 1 & $(0.03)$ & 41 & $(1.03)$ & 0 & $(0.00)$ & 1 & $(0.03)$ & 42 & $(1.05)$ & $\mathrm{a}^{* * *} \quad \mathrm{~b}^{* * *}$ \\
\hline 75 Ponceau 4R & 40 & 1 & $(0.03)$ & 49 & $(1.23)$ & 0 & $(0.00)$ & 1 & $(0.03)$ & 50 & $(1.25)$ & $\mathrm{a}^{* * *} \quad \mathrm{~b}^{* * *}$ \\
\hline 25 P. 4R-H. perforatum & 40 & 3 & $(0.08)$ & 22 & $(0.55)$ & 0 & $(0.00)$ & 0 & $(0.00)$ & 25 & $(0.63)$ & $\mathrm{a}^{* * *} \quad \mathrm{~b}^{* * *}$ \\
\hline 50 P. 4R-H. perforatum & 40 & 0 & $(0.00)$ & 33 & $(0.83)$ & 0 & $(0.00)$ & 0 & $(0.00)$ & 33 & $(0.83)$ & $a^{* * *} \quad b^{* * *}$ \\
\hline 75 P. 4R-H. perforatum & 40 & 1 & $(0.03)$ & 44 & $(1.10)$ & 0 & $(0.00)$ & 2 & $(0.05)$ & 45 & $(1.13)$ & $\mathrm{a}^{* * *} \quad \mathrm{~b}^{* * *}$ \\
\hline 25 P. 4R-S. marianum & 40 & 1 & $(0.03)$ & 26 & $(0.65)$ & 0 & $(0.00)$ & 2 & $(0.05)$ & 27 & $(0.68)$ & $\mathrm{a}^{* * *} \quad \mathrm{~b}^{* * *}$ \\
\hline 50 P. 4R-S. marianum & 40 & 3 & $(0.08)$ & 39 & $(0.98)$ & 2 & $(0.05)$ & 3 & $(0.08)$ & 44 & $(1.10)$ & $\mathrm{a}^{* * *} \mathrm{~b}^{* * *}$ \\
\hline 75 P. 4R-S. marianum & 40 & 3 & $(0.08)$ & 44 & $(1.10)$ & 0 & $(0.00)$ & 4 & $(0.10)$ & 47 & $(1.18)$ & $\mathrm{a}^{* * *} \quad \mathrm{~b}^{* * *}$ \\
\hline 25 P. 4R-L. stoechas & 40 & 1 & $(0.03)$ & 23 & $(0.58)$ & 0 & $(0.00)$ & 3 & $(0.08)$ & 24 & $(0.60)$ & $\mathrm{a}^{* * *} \mathrm{~b}^{* * *} \mathrm{c}^{*}$ \\
\hline 50 P. 4R-L. stoechas & 40 & 5 & $(0.13)$ & 41 & $(1.03)$ & 0 & $(0.00)$ & 6 & $(0.15)$ & 46 & $(1.15)$ & $\mathrm{a}^{* * *} \mathrm{~b}^{* * *} \mathrm{c}^{*}$ \\
\hline 75 P. 4R-L. stoechas & 40 & 0 & $(0.00)$ & 43 & $(1.08)$ & 0 & $(0.00)$ & 0 & $(0.00)$ & 43 & $(1.08)$ & $\mathrm{a}^{* * *} \mathrm{~b}^{* * *} \mathrm{c}^{*}$ \\
\hline $\mathrm{H}, \mathrm{P}^{\#}$ & & & & & & & & & & & & $0.63,>0.05$ \\
\hline $\mathrm{P}^{\S}$ & & & & & & & & & & & & $>0.05$ \\
\hline
\end{tabular}

P.: Ponceau, No: Number of mutant clones, Fr: Frequency; \#: It was evaluated by Kruskal-Wallis test;

§: It was evaluated by Mann-Whitney U test; X2: In evaluation with Chi-Square test; a: with Distilled water, b: with EMS, c: with Ponceau 4R; *: $\mathrm{P}<0.05, * *$ : $\mathrm{P}<0.01, * * *$ : $\mathrm{P}<0.001$

Table 2. Mutant clones in mwh/TM3 wings obtained from experimental group, treatment group, positive and negative control groups

\begin{tabular}{|c|c|c|c|c|c|c|c|c|c|c|c|c|}
\hline \multirow[t]{2}{*}{$\begin{array}{l}\text { Application } \\
\text { groups/ } \\
\text { Concentration }(\mathrm{mg} / \mathrm{ml})\end{array}$} & \multirow[t]{2}{*}{$\begin{array}{l}\text { Number } \\
\text { of wings }\end{array}$} & \multicolumn{2}{|c|}{\begin{tabular}{|c} 
Small \\
single spots \\
$(1-2$ cell $)$
\end{tabular}} & \multicolumn{2}{|c|}{\begin{tabular}{|l|} 
Large $\quad$ single \\
spots \\
$(>2$ cell $)$
\end{tabular}} & \multicolumn{2}{|c|}{ Twin spots } & \multicolumn{2}{|c|}{$\begin{array}{l}\text { Total } \\
\text { spots }\end{array}$} & \multicolumn{3}{|c|}{ Total spots $\mathrm{X} 2$} \\
\hline & & No & $\mathrm{Fr}$ & No & $\mathrm{Fr}$ & No & $\mathrm{Fr}$ & No & $\mathrm{Fr}$ & No & $\mathrm{Fr}$ & \\
\hline Distilled water & 40 & 1 & $(0.03)$ & 6 & $(0.15)$ & 0 & $(0.00)$ & 1 & $(0.03)$ & 7 & $(0.18)$ & \\
\hline $1 \mathrm{mM}$ EMS & 40 & 22 & $(0.55)$ & 66 & $(1.65)$ & 0 & $(0.00)$ & 71 & $(1.78)$ & 88 & $(2.20)$ & $\mathrm{a} * * *$ \\
\hline 25 Ponceau 4R & 40 & 1 & $(0.03)$ & 24 & $(0.60)$ & 0 & $(0.00)$ & 2 & $(0.05)$ & 25 & $(0.63)$ & $\mathrm{a}^{* * *} \mathrm{~b}^{* * * *} \mathrm{c}^{*}$ \\
\hline 50 Ponceau 4R & 40 & 0 & $(0.00)$ & 30 & $(0.75)$ & 0 & $(0.00)$ & 1 & $(0.03)$ & 30 & $(0.75)$ & $\mathrm{a}^{* * *} \mathrm{~b}^{* * *} \mathrm{c}^{*}$ \\
\hline 75 Ponceau 4R & 40 & 3 & $(0.08)$ & 44 & $(1.10)$ & 0 & $(0.00)$ & 3 & $(0.08)$ & 47 & $(1.18)$ & $\mathrm{a}^{* * *} \mathrm{~b}^{* * *} \mathrm{c}^{*}$ \\
\hline 25 P. 4R-H. perforatum & 40 & 2 & $(0.05)$ & 20 & $(0.50)$ & 0 & $(0.00)$ & 1 & $(0.03)$ & 22 & $(0.55)$ & $\mathrm{a}^{* * *} \mathrm{~b}^{* * *} \mathrm{c}^{*}$ \\
\hline 50 P. 4R-H. perforatum & 40 & 5 & $(0.13)$ & 31 & $(0.78)$ & 0 & $(0.00)$ & 5 & $(0.13)$ & 36 & $(0.90)$ & $\mathrm{a}^{* * * *} \mathrm{~b}^{* * * *} \mathrm{c}^{*}$ \\
\hline 75 P. 4R-H. perforatum & 40 & 1 & $(0.03)$ & 44 & $(1.10)$ & 0 & $(0.00)$ & 1 & $(0.03)$ & 45 & $(1.13)$ & $\mathrm{a}^{* * *} \mathrm{~b}^{* * *} \mathrm{c}^{*}$ \\
\hline 25 P. 4R-S. marianum & 40 & 0 & $(0.00)$ & 22 & $(0.55)$ & 0 & $(0.00)$ & 0 & $(0.00)$ & 22 & $(0.55)$ & $\mathrm{a}^{* * *} \mathrm{~b}^{* * * *} \mathrm{c}^{*}$ \\
\hline 50 P. 4R-S. marianum & 40 & 1 & $(0.03)$ & 26 & $(0.65)$ & 0 & $(0.00)$ & 0 & $(0.00)$ & 27 & $(0.68)$ & $\mathrm{a}^{* * *} \mathrm{~b}^{* * *} \mathrm{c}^{*}$ \\
\hline 75 P. 4R-S. marianum & 40 & 1 & $(0.03)$ & 42 & $(1.05)$ & 0 & $(0.00)$ & 0 & $(0.00)$ & 43 & $(1.08)$ & $\mathrm{a}^{* * *} \mathrm{~b}^{* * * *} \mathrm{c}^{*}$ \\
\hline 25 P. 4R-L. stoechas & 40 & 0 & $(0.00)$ & 21 & $(0.53)$ & 0 & $(0.00)$ & 3 & $(0.08)$ & 21 & $(0.53)$ & $\mathrm{a}^{* * *} \mathrm{~b}^{* * *} \mathrm{c}^{* *}$ \\
\hline 50 P. 4R-L. stoechas & 40 & 1 & $(0.03)$ & 15 & $(0.38)$ & 0 & $(0.00)$ & 1 & $(0.03)$ & 16 & $(0.40)$ & $\mathrm{a}^{* * *} \mathrm{~b}^{* * * *} \mathrm{c}^{* *}$ \\
\hline 75 P. 4R-L. stoechas & 40 & 0 & $(0.00)$ & 38 & $(0.95)$ & 0 & $(0.00)$ & 0 & $(0.00)$ & 38 & $(0.95)$ & $\mathrm{a}^{* * *} \mathrm{~b}^{* * *} \mathrm{c}^{* *}$ \\
\hline $\mathrm{H}, \mathrm{P}^{\#}$ & & & & & & & & & & & & $2.19,>0.05$ \\
\hline $\mathrm{P}^{\S}$ & & & & & & & & & & & & $>0.05$ \\
\hline
\end{tabular}

P.: Ponceau, No: Number of clones, Fr: Frequency, \#: It was evaluated by Kruskal-Wallis test;

$\S$ : It was evaluated by Mann-Whitney U test; X2: In evaluation with Chi-Square test; a: with Distilled water, b: with EMS, c: with Ponceau 4R, *: $\mathrm{P}<0.05, * *: \mathrm{P}<0.01, * * *: \mathrm{P}<0.001$

When the results of the study were evaluated, the total numbers of mutant spots in normal $(\mathrm{X} 2=213.22, \mathrm{df}=1$, $\mathrm{P}<0.001$ ) wings (in Table 1 ) and serrate $(\mathrm{X} 2=69.06, \mathrm{df}=1, \mathrm{P}<0.001)$ wings (in Table 2 ) of Drosophila flies in the positive control group was found to be much more than those of negative control group.

SMART data obtained from experimental group studies of Ponceau 4R were compared with results of positive and negative control groups. The total numbers of mutant spots in the normal wings (in Table 1) and serrate wings (in Table 2) of the Drosophila flies grown in the containing with 25\%, 50\%o and 75\%o concentrations of the Ponceau $4 \mathrm{R}$ is higher than those grown in the medium prepared with distilled water (normal wings: 
$\mathrm{X} 2=22.84, \mathrm{df}=3, \mathrm{P}<0.001$; serrate wings: $\mathrm{X} 2=29.82, \mathrm{df}=3, \mathrm{P}<0.001)$ but it was found to be less than those grown in medium with EMS addition (normal wings: $\mathrm{X} 2=330.87, \mathrm{df}=3, \mathrm{P}<0.001$; serrate wings: $\mathrm{X} 2=51.64$, $\mathrm{df}=3$, $\mathrm{P}<0.001)$.

Although the total numbers of mutant spots of the flies grown in the medium where Ponceau 4R was applied in three different concentrations increased in parallel from low concentration to high concentration, it was observed that there was no statistically difference in normal wings (in Table $1 ; \mathrm{X} 2=1.72, \mathrm{df}=2, \mathrm{P}>0.05$ ). On the other hand, it was found that the numbers of mutant spots increased in parallel with the concentrations of Ponceau $4 \mathrm{R}$ in the serrate wings (in Table $2 ; \mathrm{X} 2=7.82, \mathrm{df}=2, \mathrm{P}<0.05$ ). The total numbers of mutant spots of the wings increased gradually due to the concentrations of Ponceau $4 \mathrm{R}$ in all of the results obtained from the experimental groups.

The total numbers of mutant spots in the normal and serrate wings of the Drosophila flies grown in the mediums having three different concentrations of Ponceau $4 \mathrm{R}$ with Hypericum perforatum in $10 \%$ concentration is higher than grown that of the flies in the medium prepared with distilled water (normal wings in Table 1: X2=20.64, $\mathrm{df}=3, \mathrm{P}<0.001$; serrate wings in Table $2: \mathrm{X} 2=30.14$, $\mathrm{df}=3, \mathrm{P}<0.001$ ) but it was found to be less than those grown in medium added to EMS (normal wings in Table 1: $\mathrm{X} 2=389.87, \mathrm{df}=3, \mathrm{P}<0.001$; serrate wings in Table 2: $\mathrm{X} 2=50.86, \mathrm{df}=3, \mathrm{P}<0.001)$.

Classification of mutant clones with $m w h / f l r^{3}$ wings obtained from Ponceau $4 \mathrm{R}$ - H. perforatum

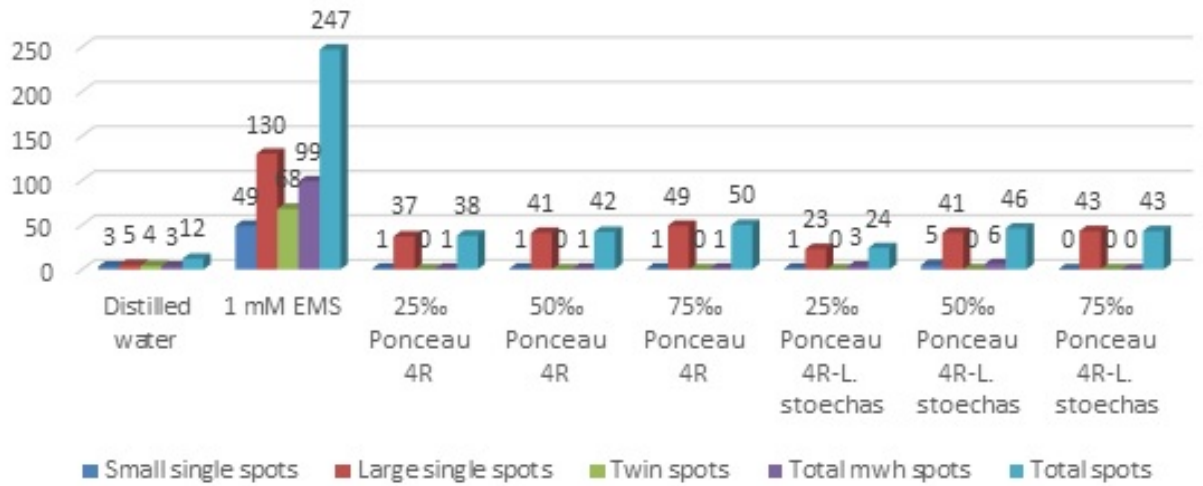

Figure 1. shows classification of mutant clones with the normal wings of the Drosophila flies in the experimental group, treatment group with Hypericum perforatum and the positive with negative control groups.

Classification of mutant clones with $m w h / T M 3$ wings obtained from Ponceau $4 \mathrm{R}-\mathrm{H}$. perforatum

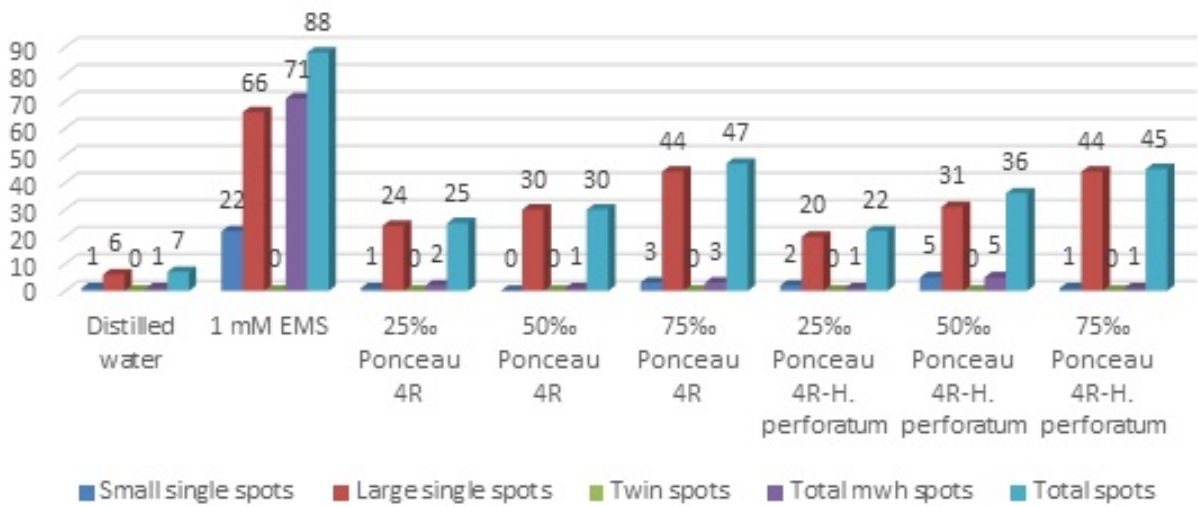

Figure 2. shows classification of mutant clones with the serrate wings of the Drosophila flies in the experimental group, treatment group with Hypericum perforatum and the positive with negative control groups.

The total numbers of mutant spots in the normal and serrate wings of the Drosophila flies grown in the mediums 
having three different concentrations of Ponceau 4R with Hypericum perforatum in $10 \%$ concentration is higher than grown in the medium prepared with distilled water (normal wings in Table 1: $\mathrm{X} 2=24.40, \mathrm{df}=3, \mathrm{P}<0.001$; serrate wings in Table 2: $\mathrm{X} 2=26.69, \mathrm{df}=3, \mathrm{P}<0.001$ ) but it was found to be less than grown in medium with EMS (normal wings in Table 1: $\mathrm{X} 2=357.05, \mathrm{df}=3, \mathrm{P}<0.001$; serrate wings in Table 2: $\mathrm{X} 2=60.13, \mathrm{df}=3, \mathrm{P}<0.001$ ).

The total numbers of mutant spots in the normal and serrate wings of the Drosophila flies grown in the mediums with three different concentrations of Ponceau $4 \mathrm{R}$ and 10\% concentration of Silybum marianum (L.) Gaertn are more than that of the flies grown in medium containing distilled water (normal wings in Table $1: \mathrm{X} 2=24.40, \mathrm{df}=3$, $\mathrm{P}<0.001$; serrat wings in Table 2: $\mathrm{X} 2=26.69, \mathrm{df}=3, \mathrm{P}<0.001$ ) but it was found to be lower than those grown in medium with EMS (normal wings in Table 1: X2 $=357.05, \mathrm{df}=3, \mathrm{P}<0.001$; serrate wings in Table 2: $\mathrm{X} 2=60.13$, $\mathrm{df}=3, \mathrm{P}<0.001)$

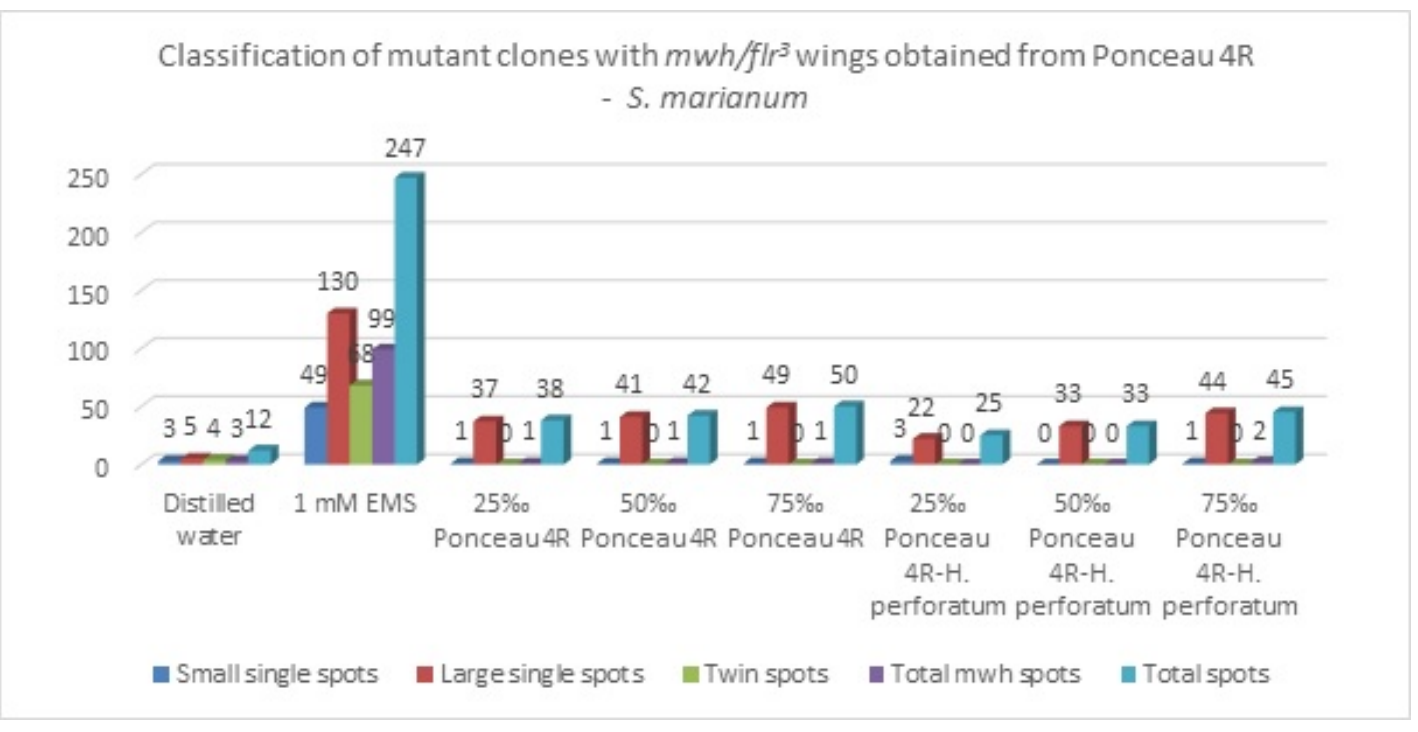

Figure 3. shows classification of mutant clones with the normal wings of the Drosophila flies in the experimental group, treatment group with Silybum marianum (L.) Gaertn. and the positive with negative control groups.

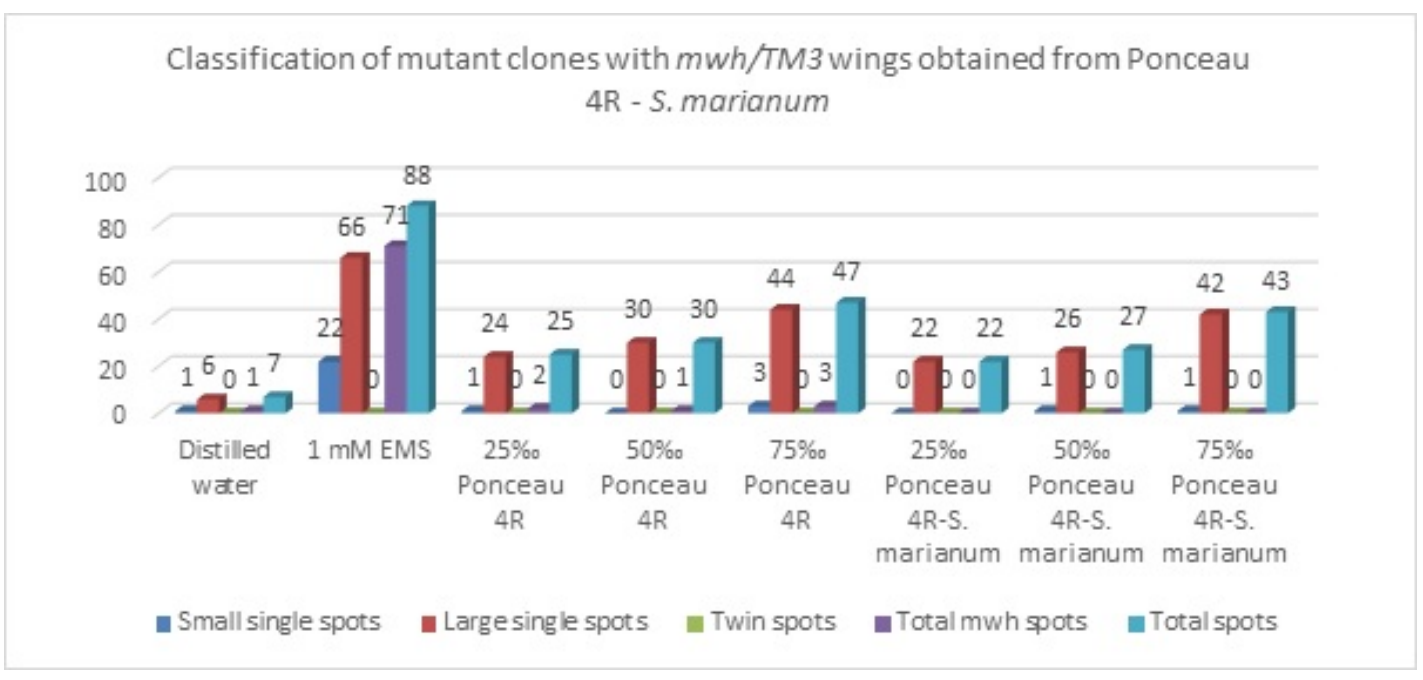

Figure 4. shows classification of mutant clones with the serrate wings of the Drosophila flies in the experimental group, treatment group with Silybum marianum (L.) Gaertn. and the positive with negative control groups. 
The total numbers of mutant spots in the normal and serrate wings of the Drosophila flies grown in the mediums having three different concentrations of Ponceau 4R with Lavandula stoechas L. in 10\% concentration are higher than that of the flies grown in the medium prepared with distilled water (normal wing in Table 1: X2=24.92, $\mathrm{df}=3, \mathrm{P}<0.001$; serrate wing in Table 2: $\mathrm{X} 2=24.83, \mathrm{df}=3, \mathrm{P}<0.001$ ) but it was found to be less than those grown in medium with EMS (normal wing in Table 1: $\mathrm{X} 2=368.33, \mathrm{df}=3, \mathrm{P}<0.001$; serrate wing in Table 2: $\mathrm{X} 2=79.57$, $\mathrm{df}=3, \mathrm{P}<0.001)$.

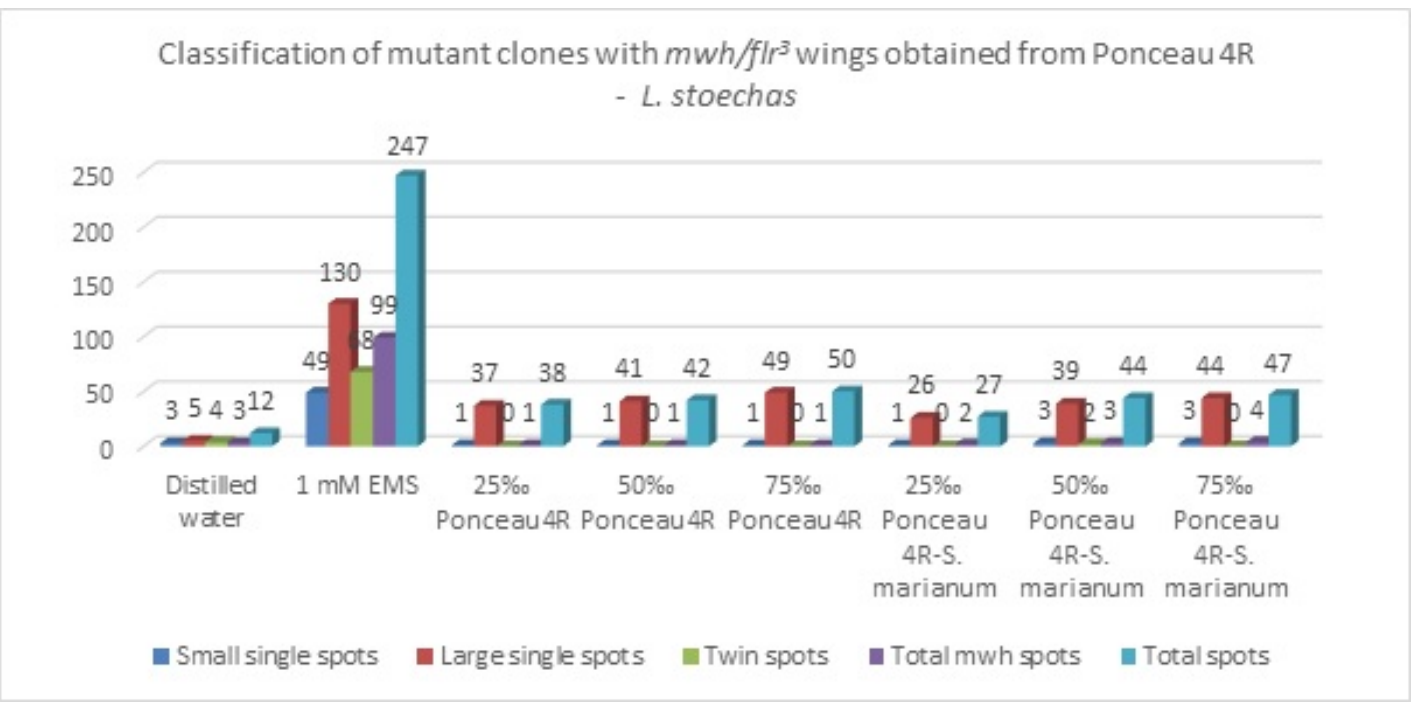

Figure 5. shows classification of mutant clones with the normal wings of the Drosophila flies in the experimental group, treatment group with Lavandula stoechas L. and the positive and negative control groups.

Classification of mutant clones with $m w h / T M 3$ wings obtained from Ponceau

$4 R$ - L. stoechas

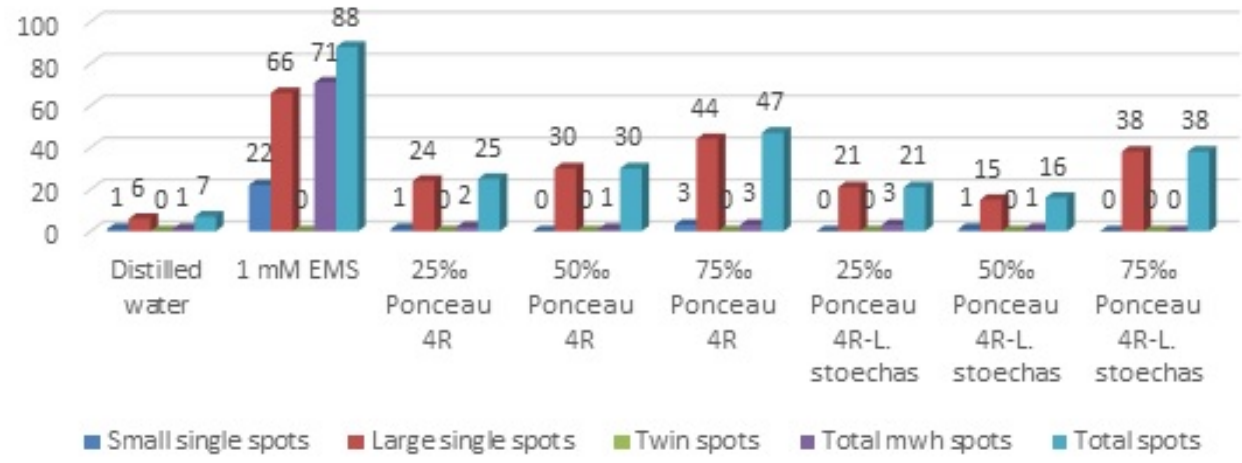

Figure 6. shows classification of mutant clones with the serrate wings of the Drosophila flies in the experimental group, treatment group with Lavandula stoechas L. and the positive and negative control groups.

Statistical analysis shows that total numbers of mutant spots in the wings of the flies in all experimental and treatment groups increased gradually depending on the concentration of Ponceau 4R.

While numerical differences between the total numbers of mutant spots in the normal wings of the flies are evaluated in the experimental group with three different concentrations of Ponceau $4 \mathrm{R}(\mathrm{X} 2=1.72 \mathrm{df}=2, \mathrm{P}>0.05)$, in treatment group in which three different concentrations of Ponceau $4 \mathrm{R}$ and Hypericum perforatum $(\mathrm{X} 2=5.90$ 
$\mathrm{df}=2, \mathrm{P}>0.05$ ) and in treatment group in which three different concentrations of Ponceau $4 \mathrm{R}$ and Silybum marianum (L.) Gaertn $(\mathrm{X} 2=5.91 \mathrm{df}=2, \mathrm{P}>0.05)$ have not statistically significant, in treatment group in which three different concentrations of Ponceau $4 \mathrm{R}$ and Lavandula stoechas $\mathrm{L}$. $(\mathrm{X} 2=7.55, \mathrm{df}=2, \mathrm{P}<0.05)$ they have statistical significance. In other words, the total numbers of mutant wing spots within themselves of the treatment groups in which Ponceau 4R and the plant extracts does not significant differences. However, statistical differences of the total numbers of mutant spots in the serrate wings of the flies are significant depend on the concentration in the experimental group $(\mathrm{X} 2=7.82 \mathrm{df}=2, \mathrm{P}<0.05)$, in the treatment group in which Ponceau 4R and seperately Hypericum perforatum $(\mathrm{X} 2=7.83 \mathrm{df}=2, \mathrm{P}<0.05)$, in the treatment group with Ponceau 4R and Silybum marianum (L.) Gaertn $(\mathrm{X} 2=7.85 \mathrm{df}=2, \mathrm{P}<0.05)$ and in the treatment group with Ponceau 4R and Lavandula stoechas L. $(\mathrm{X} 2=10.64, \mathrm{df}=2, \mathrm{P}<0.05)$.

When average numbers of mutant spots in normal wings $(\mathrm{H}=0.63 ; \mathrm{df}=3, \mathrm{P}>0.05)$ and serrate wings $(\mathrm{H}=2.19$; $\mathrm{df}=3, \mathrm{P}>0.05$ ) of flies in the experimental group with three different concentrations of Ponceau $4 \mathrm{R}$ and in the treatment groups in which three different concentrations of Ponceau 4R were together with separately Hypericum perforatum, Silybum.marianum, Lavandula stoechas L. were compared with each other, it was observed that results found were not different.

Finally, when average of total numbers of mutant spots in the normal and serrate wings of the flies in the experimental and treatment groups were compared with each other, it was revealed to be not statistically differences $(\mathrm{P}>0.05)$.

\section{Conclusion}

When the study data are evaluated for genotoxicity by using SMART, it has become clear that Ponceau 4R has mutagenic effects in normal and serrate wings of Drosophila flies in studied concentrations. This clearly shows that this red colouring has a genotoxic effect in the imaginal disc cells that will develop into the wing spot cells during the embryonic development of Drosophila heterozygous larvae, and the genotypic changes caused by mutation or recombination in somatic cells also play a role in the formation of mutant spots in the wings. Serrate wings of fruit flies contain only clones resulting from mutation, while mutant clones resulting from both mutation and recombination can be seen in normal wings (KAYA et al., 1999; ZORDAN et al., 1994). In addition, the mutagenic effect of Ponceau 4R was found to be stronger due to its increasing concentrations. Because total numbers of mutant clones induced in Drosophila flies added with Ponceau 4R is a result of the genotoxic activity of this genotoxic agent due to the increase in concentration. These results are similar to the following studies about genotoxicity of Ponceau 4R. (UYSAL \& SEMERDOKEN, 2011) showed that increased toxicity in Drosophila larvae at $72 \pm 4$ hours due to the concentration increase of Ponceau 4R. (SEMERDOKEN, 2012) reported increase in the mortality rate of Oregon $R$ wild and Vestigial mutant strains of Drosophila larvae (72 \pm 4 hours) as the application concentration of Ponceau 4R increases. (TURKOGLU et al., 2015) published that the longevity of Drosophila melanogaster decreased significant, depend on the different concentrations of Ponceau 4R. (UYSAL et al., 2017) notified that maximum mean life of Oregon R wild of D. melanogaster larvae at $72 \pm 4$ hours decreased in different concentrations of Ponceau $4 \mathrm{R}$ depend on feeding. These studies data are compatible and supports the results of the study.

Hypericum perforatum L., Silybum marianum (L.) Gaertn. and Lavandula stoechas L. didn't show reducing or preventive effects on mutations caused by Ponceau 4R. When the average of the total numbers of mutant spots on wings of the flies in Ponceau 4R treatment and experiment groups were compared with each other, it didn't have any difference.

When the literature is examined, it is seen that there are a few studies about antigenotoxicity of the plant extracts in D. melanogaster Meigen. It was also given below that similar antigenotoxitiy studies in various model organisms about the plant extracts evaluated with different test systems.

(NEO et al., 2011) reported that Hypericum perforatum L. in $2.5 \%, 12.5 \%$ and $50 \%$ concentrations slowed cell death in Drosophila cells by suppressing the expression of denatured proteins. (UYSAL et al., 2007) showed that when Hypericum perforatum L. in different concentrations didn't cause elongation of D. melanogaster Meigen F1 progeny trasformation time to adult, increased numbers of offspring due to increase in concentrations and had highest numbers of offspring at concentration of $10 \mathrm{ml} / 100 \mathrm{ml}$. (BRANDA et al., 2006) published that Hypericum perforatum L. taken with diet was ineffective on leukopenia caused by chemotheropathic drugs on experimental cancer model induced in rats. (MARTARELLI et al., 2004) notified that while Hypericum perforatum L. prepared in methanol $80 \%$ reduced rate of growth and development of prostate adenocarcinoma cells in humans, $70 \%$ experimental cancer induced in mice. 
(CAN 2014) reported that Silybum marianum (L.) taken with diet in $10 \%$ concentration reduced DNA damage and apoptosis in rats which liver damage induced by carbon tetrachloride. (ZHOU et al., 2006) showed that active substances of Silybum marianum (L.) was effective in reducing DNA damage and regulation of cell cycle in rats. (GARCIA-MACEIRA \& MATEO, 2009) published that cervical and liver cancers in humans are inhibited by Silybum marianum (L.).

(KULCANAY, 1998) notified that when oil with leaf and flower extracts of Lavandula stoechas L. evaluated with Salmonella/microsome test, they were mutagenic. (AYRAL, 1997) reported that while some of essential oil compounds in above ground parts of Lavandula stoechas L. had strong cytotoxic and antibacterial effects in different cancer cells. (MARGO et al., (2006) showed that when one of the antigenotoxic effects of Lavandula stoechas L. tested for fungistatic (delaying or inhibiting fungal growth) activity in various mushrooms, the plant extract was ineffective.

Results of the researches above mentioned and these study data are not parallel to each other. Accordingly, the study data show that these plant extracts were ineffective in the $10 \%$ concentration studied as a single dose in protecting Drosophila flies against the genotoxicity of the synthetic food colouring. The plant extracts can be used in different concentrations and for longer periods of time. Furthermore, more basic and clinical studies are need to be determined for effectiveness of the plant extracts. It is necessary to investigate additionally combined use of the plant extracts and their applicability to various drugs.

Ponceau 4R is used in various experimental organisms for scientific researches on toxicological, histopathological, carcinogenic and teratogenic effects. It is thought that this study can contribute to scientific researches and similar experiments will do later. More scientific studies are required to explain molecular mechanisms and distributions of the genotoxicity of the food coloring used in the study and the antigenotoxicity of the plant extracts by using in vivo and in vitro test systems in/on different model organisms.

Results of the study are remarkable since application of SMART in vivo conditions (BERNARDS \& HARIHARAN, 2001, GRAF et al., 1984) and investigation of the genotoxic and antigenotoxic effects of different chemical substances in eukaryotic D. melanogaster Meigen as a model organism instead of mammals.

Since biological properties of imaginal disc cells in which Drosophila larvae undergoe proliferation and differentiation in adult are similarity with many cancer-sensitive mammalian cells and more than $60 \%$ of the genes determined in human genetic diseases are common with the Drosophila genome (YAMAN, 1996) value of results of the study increase.

As shown food additives used in similiar studies, the use of the food coloring in the study in a way that is not in accordance with the regulation may cause toxic effects on humans. Therefore, food additives should be consumed in a more controlled manner. Protecting public health can maintain genomic stability against the damage caused by the synthetic food colourings.

Determining the efficacy and safety of the plant extracts is closely related to the health of today and in the future generations. When taking into account the effects of the synthetic food colouring and the plants extracts used in the study public health should be protected by changing eating habits. Future studies will carry out on food colorings and plant extracts will help people in the following years because they will be of great importance for the continuity in healthy life.

\section{References}

Akbulut, M., (2011): Food additives: functions and resources. 1.Ulusal Helal ve Sağllklı Glda Kongresi, Kasım 19-20, 2011, Ankara, Türkiye.

Ayral M.N., (1997): Lavandula stoechas ssp. stoechas Bitkisinin Uçucu Yağının ve Uçucu Olmayan Organik Bileşenlerinin İncelenmesi ve Biyolojik Aktivitelerinin Belirlenmesi. Yüksek Lisans Tezi, Marmara Üniversitesi Fen Bilimleri Enstitüsü, İstanbul.

Branda R.F., Powden C., Brooks E.M., Yildirim Z., Naud S.J., Mccormack J. J., (2006): Vitamin E but not St. John's wort mitigates leukopenia caused by cancer chemotherapy in rats. Transl Res., 148(6), 315-324. https://doi.org/10.1016/j.trsl.2006.05.007

Can M.İ., (2014): Karbon tetraklorür (CCl4) ile Karaciğer Hasarl Oluşturulmuş Ratlarda Deve dikeni (Silybum marianum L.) 'nin Kaspaz-3, Kaspaz-9, Bax, BCL-2 Proteinlerinin Ekspresyonu ve DNA Hasarı Üzerine Etkisi. Yüksek Lisans Tezi, Fırat Üniversitesi Fen Bilimleri Enstitüsü, Elazığ.

Garcia-Bellido A. \& Dapena J., (1974): Induction, detection and characterization of cell differentiation mutations 
in Drosophila. Mol. Gen. Genet., 128, 117-130. https://doi.org/10.1007/BF02654485

Garcia-Maceira P., Mateo J., (2009): Silibinin inhibits hypoxia-inducible factor-1a and mTOR/p70S6K/4E-BP1 signalling pathway in human cervical and hepatoma cancer cells: implications for anticancer therapy. Oncogene, 28, 313-324. https://doi.org/10.1038/onc.2008.398

Graf U., Wurgler F.E., Katz A.J., Frei H., Juan H., Hall C.B., Kale P.G., (1984): Somatic mutation and recombination test in Drosophila melanogaster. Environ. Mutagen., 6, 153-188.

https://doi.org/10.1002/em.2860060206

Graf U. \& Wurgler F.E., (1996): The somatic white-ivory eye spot test does not detect the same spectrum of genotoxic events as the wing somatic mutation and recombination test in Drosophila melanogaster. Environ. Mol. Mutagen., 27, 219-226.

https://doi.org/10.1002/(sici)1098-2280(1996)27:3\%3C219::aid-em7\%3E3.0.co;2-9

Kasimoğlu C. \& Uysal H., (2016): Genoprotective effects of aqueous extracts of Rosa canina L. fruits on ethyl methanesulfonate-1nduced DNA damage in Drosophila melanogaster. Cumhuriyet Science Journal, 37(3), 241-247. https://doi.org/10.17776/csj.18487

Kaya B., (2000): Investigation of mutagenic and recombinogenic effects of some pesticides on Drosophila melanogaster lines. Akdeniz Üniversitesi Fen Bilimleri Enstitüsü Yayınlarl, Antalya, Türkiye.

Kaya B., Yanikoğlu A., Marcos R., (1999): Genotoxicity studies on the phenoxyacetates 2,4-D and 4-CPA in the Drosophila wing spot test. Teratogen. Carcinogen. and Mutagen., 19, 305-312. https://doi.org/10.1002/(SICI)1520-6866(1999)19:4\%3C305::AID-TCM7\%3E3.0.CO;2-X

Kulcanay I., (1998): Lavandula stoechas L. Bitki Ekstre ve Yağının Ames/Salmonella/Mikrozom Test Sistemi ile Mutajenitesinin Araştırllması. Yüksek Lisans Tezi, Osmangazi Üniversitesi Fen Bilimleri Enstitüsü, Eskişehir.

Lindsley D.L. \& Grell E.H., (1968): Genetic variations of Drosophila melanogaster. Carnegie Institutution of Washington Publ., Washington DC, 627, p 472. https://doi.org/10.1126/science.162.3857.993

Lindsley D.L. \& Zimm G.G., (1992): The genome of Drosophila melanogaster. Academic Press, San Diego, CA, p 1133.

Maier E., Kurz K., Jenny M., Schennach H., (2010): Food preservatives sodium benzoate and propionic acid and colourant curcumin suppress Th1-type immune response in vitro. Food Chem. Toxicol., 48, 19501956. https://doi.org/10.1002/bies.950150612

Margo A., Carolino M., Bastos M., Mexia A., (2006): Efficacy of plant extracts against stored-products fungi. Rev Iberoam Micol., 23(3), 176-178. https://doi.org/10.1016/s1130-1406(06)70039-0

Martarelli D., Martarelli B., Pediconi D., Nabissi M.I., Perfumi M., Pompei P., (2004): Hypericum perforatum methanolic extract inhibits growth of human prostatic carcinoma cell line orthotopically implanted in nude mice. Cancer Lett., 210,27-33. https://doi.org/10.1016/j.canlet.2004.01.031

Neo A., Tan D., Ferguson A., Morris C., (2011): Investigation of the Effects of St John's Wort on Cancer and Drosophila. AOS-HCI Combined Research Paper, Hwa Chong Institution, Singapore.

Tripathy N.K., Patnaik K.K., Nabi M.J., (1989): Genotoxcicity of tartrazine studied in two somatic assays of Drosophila melanogaster. Mutation Research, 224 (4), 479-83.

https://doi.org/10.1016/0165-1218(89)90073-6

Sarikaya R., Selvi M., Akkaya N., Acar M., Erkoc F., (2010): The effect of food dyes of different concentrations on the percentage of living in Drosophila melanogaster (mwh x flr). Süleyman Demirel Üniversitesi Fen Dergisi, 5, 38-46.

Semerdoken S., (2012): Effects of some synthetic azo food dyes added to foodstuffs on larval mortality and longevity of Drosophila melanogaster's oregon R wild and vestigial mutant strains. Atatürk Üniversitesi Fen Bilimleri Enstitüsü Yayınları, Erzurum, Türkiye.

Topsoy H., (1990): Quantification of synthetic paints added to some sugary foods. Ankara Üniversitesi Sağllk Bilimleri Enstitüsü Yayınlarl, Ankara, Türkiye.

Turkoglu S., Benli D., Sahin D., ( 2015): The effects of five food dyes on the longevity of Drosophila melanogaster. Fresenius Environmental Bulletin, 24(9), 2830-2836.

Uysal H., Genç S., Ayar A., (2017): Toxic effects of chronic feeding with food azo dyes on Drosophila 
melanogaster Oregon R. Scientia Iranica C, 24(6), 3081-3086.

https://dx.doi.org/10.24200/sci.2017.4523

Uysal H. \& Semerdoken S., (2011): Determination of the effects of Drosophila melanogaster on synthetic food paints on larval toxicity and adult longevity in oregon R line. Kafkas Üniversitesi Fen Bilimleri Enstitüsü Dergisi, 4(1), 71-87.

Uysal H., Kara A.A., Algur O.F., Dumlupinar R., Aydogan M.N., (2007): Recovering effects of aqueous extracts of some selected medical plants on the teratogenic effects during the development of D. Melanogaster. Pak J Biol Sci., 15, 10(10), 1708-1712. https://doi.org/10.3923/pjbs.2007.1708.1712

Yaman M., (1996): Investigation of synthetic dye amount added to some foodstuffs. Gazi Üniversitesi Sosyal Bilimleri Enstitüsü Yayınlarl, Ankara, Türkiye.

Yentur G., Eksi A., Bayhan A., (1996): Investigation of the amount of synthetic dye in cake decorations and some candies provided from Ankara market. Ankara Üniversitesi Veteriner Fakültesi Dergisi, 43, 479484.

Zhou B., Wu L.J., Tashiro S., Onodera S., Uchiumi F., Ikejima T., (2006): Silibinin Protects Rat Cardiac Myocyte from Isoporoterenol-Induced DNA Damage Independent on Regulation of Cell Cycle. Biological and Pharmaceutical Bulletin, 29 (9), 1900-1905.

Zordan M., Osti M., Pesce M., Costa R., (1994): Chloral hydrate is recombinogenic in the wing spot test in Drosophila melanogaster. Mutat. Res., 322, 111-116. https://doi.org/10.1016/0165-1218(94)00017-4 